\title{
VLASTOS E A ESCRAVIDÃO EM PLATÃO
}

\section{Alice Bitencourt Haddad*}

* Universidade

Federal Rural

do Rio de Janeiro.

\begin{abstract}
RESUMO: Vlastos, num artigo intitulado "Slavery in Plato's Thought", sustenta, entre outras coisas, a tese de que Platão teria influenciado Aristóteles em sua defesa da escravidão natural, considerando a relação entre governantes e governados na cidade excelente da República um exemplo que se conformaria a essa doutrina. Há, entretanto, vários indícios que o desmentem, tais como a associação da sōphrosynē à harmonia entre os cidadãos, que têm uma opinião comum sobre quem deve governar, além da frequente vinculação da escravidão a violência, tirania e sujeição, o que contradiz a qualificação de virtuosa e amigável douleia, suposta por Vlastos e atribuída a Platão.
\end{abstract}

PALAVRAS-CHAVE: Vlastos, Platão, República, escravidão.

\section{VLASTOS AND THE SLAVERY IN PLATO}

\begin{abstract}
Vlastos, in an article entitled "Slavery in Plato's Thought", holds, among other things, an opinion that Plato would have influenced Aristotle in his defense of natural slavery, regarding the relationship between government and governed in Republic's excellent state as an example which would be in accordance with this theory. However, there are many clues that deny it, such as the connection between sōphrosyne and the harmony among citizens, which have a common opinion about who may command, as well as the recurrent link between slavery and violence, despotism and subjection, which contradicts the description of a virtuous and amicable douleia, proposed by Vlastos and attributed to Plato.
\end{abstract}

KEYWORDS: Vlastos. Plato. Republic. Slavery.

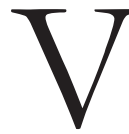

lastos, em seu artigo "Slavery in Plato's Thought", publicado na Philosophical Review de maio de 1941, procura tratar do tema da escravidão de maneira oblíqua, buscando as poucas alusões que Platão faz ao tema, uma vez que não há lugar em sua obra em que o filósofo aborde o assunto de maneira explícita e 
extensa. ${ }^{1}$ As passagens que ele escolhe para abrir o artigo são já anunciadoras da leitura que ele faz de Platão, que conclui com a afirmação de que para o filósofo, assim como para Aristóteles, a escravidão seria natural, decorrente da privação natural do logos na maioria dos homens. As passagens transcritas por ele logo no primeiro parágrafo são das Leis, 720, 773 e 996.

A primeira descreve dois tipos de médico: os médicos e os ajudantes dos médicos

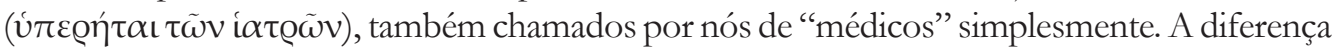

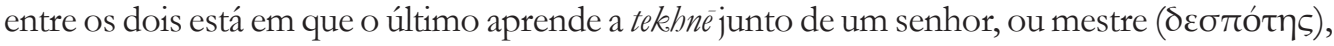
por meio da observação ( $\theta \varepsilon \omega \varrho i ́ \alpha v)$ e da experiência ( $\kappa \alpha \tau$ ' $\varepsilon \mu \tau \varepsilon\llcorner\varrho i ́ \alpha v)$, enquanto o médico livre aprende por si mesmo a physis, a natureza. Semelhantes a escravos, os primeiros médicos

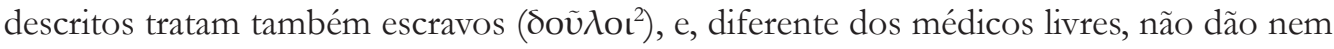

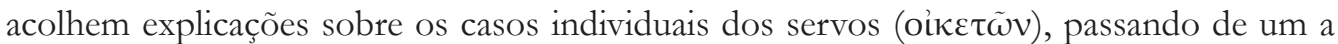
outro e livrando seu senhor de se ocupar deles. Seu senhor, por outro lado, cuidando dos homens livres somente, além de examinar e tratar as doenças, se preocupa em comunicar suas impressões ao paciente, aprende com eles, se instrui, assim, sobre o assunto, e não lhe prescreve nada sem o haver antes persuadido. Duas coisas se fazem notar na passagem em questão e que interessaram para a análise de Vlastos. Primeiro, o ajudante de médico tem um saber parcial ou precário das doenças, não sendo um conhecedor da physis, e apenas tomando a tekhnē médica como uma rotina segundo a qual ele aplica nos doentes que trata aquilo que ele viu o médico-senhor fazer com os seus. Nesse sentido ele é um repetidor dos atos do médico-senhor e não saberia explicá-los. É por isso que ele seria incapaz de também explicar seus procedimentos ao paciente. Em segundo lugar, o paciente escravo também parece, embora o texto não seja explícito quanto a isso, incapaz de acolher a explicação acerca de sua doença e de ele mesmo colaborar com o médico, instruindo-o. Além disso, o escravo não se inclui entre os pacientes que podem ou devem ser persuadidos antes de iniciar o tratamento.

$\mathrm{Na}$ segunda passagem escolhida por Vlastos para abrir seu artigo, ${ }^{3}$ encontramos os personagens discutindo como se dará a escravidão na cidade que está sendo fundada, e o Ateniense conclui a polêmica acerca de como tratar os escravos da seguinte forma:

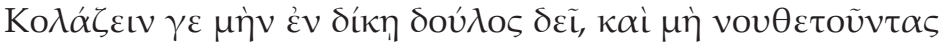

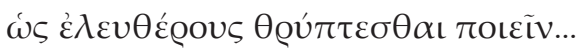
É preciso, então, castigar os escravos com justiça, e não fazê-los se abaterem conduzindo-os à reflexão como se fossem livres ${ }^{4}$ (Leis, 777e5-6).

\footnotetext{
${ }^{1}$ Segundo Cuffel (1966, p. 323), essa "pouca atenção" dada ao tema se verificaria de maneira geral nos autores da época, que tinham a presença do escravo como um fato do cotidiano.

${ }^{2}$ Termo grego ao qual devemos nos remeter sempre que Vlastos escreve "slaves". Termo de significado semelhante é oiketès, que ele traduz por "servant".

${ }^{3} \mathrm{Na}$ edição da Belles Lettres, o trecho citado por ele se encontra em 777e, e não em 773e.

${ }^{4}$ Esta e as demais traduções são nossas.
} 
$\mathrm{Na}$ terceira passagem, consideração bastante semelhante às duas anteriores pode ser vista na discussão sobre a formação dos guardiões da cidade cuja constituição vem sendo elaborada. Em 966b o Ateniense afirma que os que são realmente guardiões (

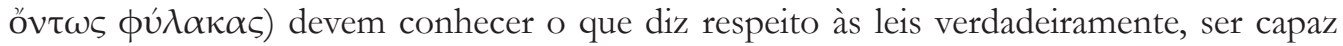
de interpretá-las e segui-las por meio de feitos, discernindo o que vem a ser belo ou não segundo a natureza. O ponto é que o guardião das leis não deve apenas conhecer, saber, mas

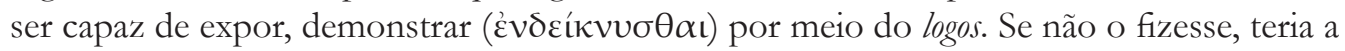
mentalidade ${ }^{5}$ de um andrápodon, de um cativo.

O escravo de Platão trazido por Vlastos é aquele incapaz de ser persuadido, de acolher um logos admoestador e incapaz de dar as razões de seus atos. É um escravo, enfim, sob o aspecto cognitivo.

Na sequência do artigo, o autor leva o tema da escravidão para a discussão de Platão com o materialismo jônico, discussão em que o filósofo se opõe a adotar a causa mecânica, chamada por ele de causa escrava, como a verdadeira maneira de entender o movimento dos corpos. A causa pela qual podemos explicar por que a coisas se movem ou estão dispostas de determinada maneira é a causa inteligente, divina, que atua em vista do bem, aquela que Aristóteles chamou de causa final. Não gostaríamos de nos deter no assunto, embora devamos dizer que Vlastos traz uma análise bastante original e interessante sobre ele. Porém o que nos motiva a ler seu artigo e problematizá-lo é o confronto que se pode estabelecer entre sua visão do escravo em Platão e a maneira como o tema da escravidão é trabalhado na República. Segundo o comentador, todos aqueles que não conhecem a Ideia de Bem, isto é, a grande maioria dos habitantes da cidade construída por Sócrates e seus companheiros, podem ser considerados escravos daqueles que a conhecem. A única maneira de aqueles fazerem o bem seria por meio da obediência aos seus superiores, e os artesãos seriam, portanto, escravos dos filósofos (é claro que o autor está tomando "escravidão" ainda naquele sentido cognitivo, do início de seu artigo, e não no sentido político, legal).

A leitura de Vlastos nos parece a princípio problemática por causa da caracterização da cidade sōphrōn elaborada por Platão. O comentador questiona: "Como homens que não conhecem a natureza da justiça podem estabelecer um estado pelo comum acordo?” (Vlastos, 1941, p. 291). Entendemos que essa é uma questão legítima, pertinente, mas Sócrates afirma na República que a sōphrosynè, uma das qualidades da cidade excelente, se assemelha a uma symphōnia (um acorde) e a uma harmonia (República, IV, 430e3-4). Politicamente, essa harmonia e esse acorde se refletem na doxa comum a governantes e governados sobre quem deve governar (República, IV, 431d10-e2). ${ }^{6}$

Dando razão a Vlastos, por outro lado, há no próprio texto de Platão certa ambiguidade na abordagem da sōphrosynē. Inicialmente o Estado sōphrōn é descrito como

\footnotetext{
${ }^{5}$ Como traduz héxis Diès, na edição da Belles Lettres.

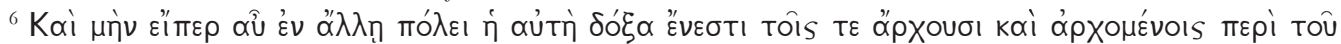

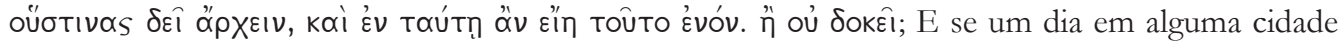
existir a mesma opinião entre governantes e governados acerca de quem deles deve governar, seria na nossa que haveria isso; ou não lhe parece assim?
} 
aquele em que os desejos dos muitos e fracos são dominados pelos desejos e pela inteligência

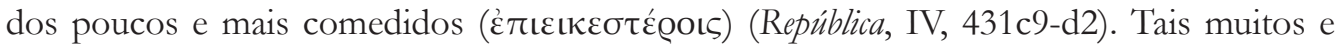
fracos são identificados, em passagem um pouco anterior, com crianças, mulheres, servos e muitos dos chamados homens livres, na verdade homens phauloi, inferiores (República, IV, 431c1-5). Numa primeira análise, pode-se, de fato, enxergar nessa primeira descrição do Estado sōphrōn a disjunção proposta por Vlastos entre quem domina e quem obedece. Essa

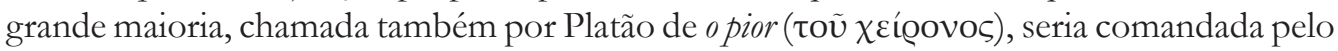

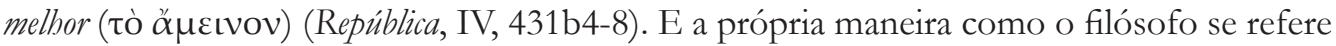
aos homens inferiores, deixando claro que são apenas ditos livres ( $\dot{\lambda} \lambda \varepsilon v \theta \varepsilon \dot{\varrho} \omega \nu \lambda \varepsilon \gamma O \mu \varepsilon \dot{v} \omega v)$, oferece subsídios para a tese de Vlastos.

Apesar disso, à medida que a leitura do texto da República avança, percebemos que tal visão não se sustenta. ${ }^{7}$ Isso porque não apenas Platão redefine a sōphrosynē por meio das imagens da harmonia e do acorde, e alegando a existência de uma doxa comum entre governantes e governados, mas também porque a estrutura mesma da cidade construída não corresponde à estrutura da cidade histórica, de modo que as mulheres, as crianças, os servos e os ditos homens livres têm outra inserção nessa polis, o que faz com que não possam mais ser, de maneira apressada, reconhecidos como os piores, aqueles onde se encontram os muitos e diversos desejos, prazeres e dores (como havia dito Platão em República, IV, 431b10-c3).

Com relação às crianças, o livro IX é bem esclarecedor: elas não devem ser livres enquanto não tiverem estabelecido em si mesmas um guardião e governante (República, IX, 590e1-591a3). Elas devem ser obedientes a comandantes externos enquanto seus comandantes internos não estão desenvolvidos.

Já as mulheres não podem ser todas consideradas entre os piores. Aquelas que tiverem natureza de guardiã receberão a mesma educação que os homens e poderão, inclusive, governar, passando para o outro lado daquela disjunção inicialmente proposta por Platão.

O tratamento que Platão dedica aos servos, oiketai, na cidade construída corrobora ainda mais com a nossa interpretação de que tal grupo dos piores é apenas uma imagem retirada da cidade histórica. Afinal, os servos não existem na polis excelente! Pelo menos não há servos dentre os cidadãos. O mesmo não afirmaríamos com tanta veemência com relação aos bárbaros. Embora Platão não se dedique, novamente, ao assunto de maneira pormenorizada, no livro IV, em 433d, ele inclui entre habitantes da cidade que devem realizar

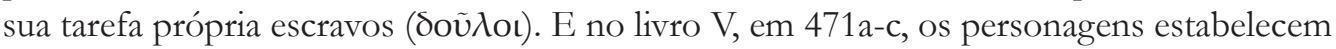
que os guardiões não deverão travar guerra ( $\pi$ ó $\lambda \varepsilon \mu$ s) contra cidades gregas, mas que,

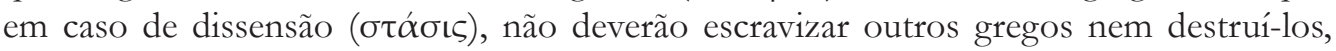
mas tratar como inimigos apenas os poucos responsáveis pela discórdia, e não uma cidade inteira, devastando territórios e queimando casas. Com relação aos bárbaros, diz Sócrates, os guardiões devem se portar como os gregos hoje se portam contra os outros gregos, ou seja, sem atenção a nenhuma dessas recomendações. Assim está claro que a escravidão de um

\footnotetext{
${ }^{7}$ Defendemos essa interpretação de maneira bem mais detalhada em Haddad 2010.
} 
bárbaro seria permitida. ${ }^{8}$ Por outro lado, voltando à questão dos oiketai, o termo mesmo só aparece quando a cidade excelente decai para uma timocracia. Os governantes e guardiões, agora de natureza irregular e desarmônica, deixarão de guardar seus concidadãos, antes

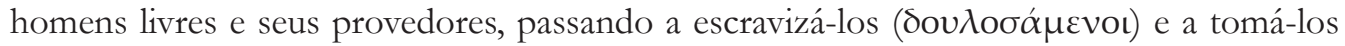

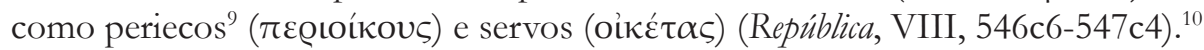

Essa passagem, aliás, é fundamental para nos levar a questionar a visão de Vlastos acerca da escravidão em Platão, pelo menos na República. Não há momento algum em que o filósofo utilize a palavra doulos ou oiketēes, ${ }^{11}$ nem metaforicamente, para se referir ao conjunto de governados daquele Estado. A primeira ocorrência de oiketés após a passagem do livro IV só vai aparecer no livro IX, na passagem que acabamos de citar. Quanto a doulos, há 16 ocorrências. A primeira, que diz respeito especificamente ao escravo como um habitante da cidade, se encontra no livro IV, numa passagem à qual já fizemos alusão ao falar da possibilidade do escravo bárbaro; em 433d, ao falar da justiça na cidade como uma virtude presente em todos os habitantes, com cada um realizando aquilo que lhe é próprio. São eles crianças, mulheres, escravos (ઠoú $\lambda \omega$ ), homens livres, artesãos, governantes e governados. Nada aí aponta para a associação entre governados, de maneira geral, e escravos.

Platão não poderia nos munir melhor contra a tese de Vlastos senão com uma passagem do livro V, 463a-b, em defesa da união da cidade por meio da comunidade de mulheres e crianças, que vale a pena citar:

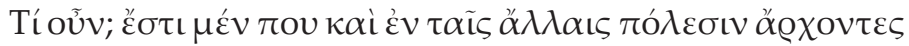

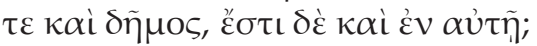

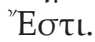

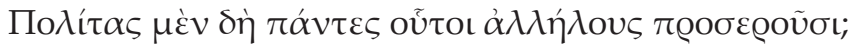

$\Pi \tilde{\omega} \varsigma \delta$ 'oü;

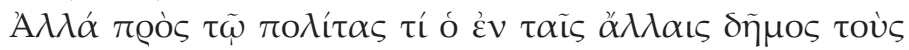

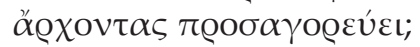

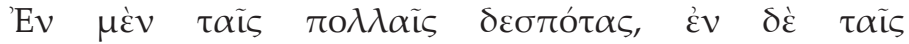

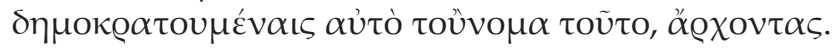

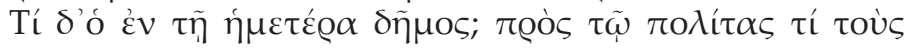

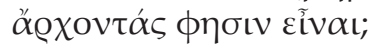

\footnotetext{
${ }^{8}$ É o que pensa também Newman 2010, p. 143, n. 3: “Essa classe (a terceira) é provavelmente concebida como helênica, assim como as duas classes superiores, e o fato de não haver uma classe-escrava no Estado ideal da República não necessariamente implica a não existência da escravidão nesse Estado: pelo contrário, a escravidão é aqui e ali tacitamente implicada como existindo nela".

${ }^{9}$ No contexto da cidade histórica, seriam os residentes nas cercanias da cidade, sem direitos políticos plenos.

${ }^{10}$ Toda essa argumentação acerca dos servos retiramos de Haddad 2010, p. 209 e 2011.

${ }^{11}$ Para maiores detalhes acerca do uso do termo oiketés na República, recomendo o artigo que vimos citando, Haddad 2010. Quanto a doulos, uma busca no Perseus Digital Library aponta 16 ocorrências, em I, 351d; III, 395e; IV, 433d; V, 463b e 469c; VIII, 549a, 567e, 569a e 569c; IX, 577c, 577d, 579a, $579 \mathrm{~d}, 587 \mathrm{c}, 590 \mathrm{c}$ e $590 \mathrm{~d}$.
} 


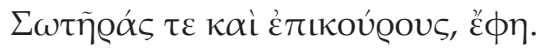

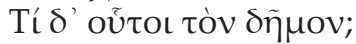

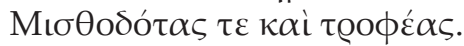

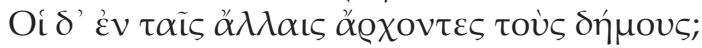

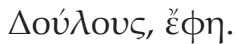

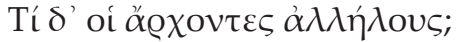

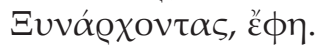

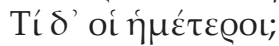

$\Xi v \mu \phi \hat{u} \lambda \alpha \kappa \alpha \varsigma$.

Então? Há nas outras cidades, além de nesta, tanto governantes quanto povo?

Há.

E todos eles se chamam uns aos outros de cidadãos?

Como não?

Mas, além de cidadãos, como o povo nas outras cidades designam os governantes?

Nas outras cidades, soberanos, mas naquelas democráticas este é o nome mesmo: governantes.

Quanto ao povo na nossa cidade? Além de cidadãos, o que ele diz serem os governantes?

Salvadores e auxiliares, disse.

E o que estes dizem do povo?

Que são distribuidores de salários e alimentação.

E como os governantes nas outras cidades chamam os povos?

Escravos, disse.

E os governantes entre si?

De parceiros no comando, ${ }^{12}$ disse.

E os nossos governantes?

De parceiros na guarda. (República, 463a1-9).

Platão não poderia ser mais explícito do que nessa passagem. Nas outras cidades o povo é chamado de escravo, mas na "nossa" não. Nem os governantes podem ser considerados soberanos, senhores, mas aqueles que salvam, guardam.

É preciso, entretanto, fazer uma importante ressalva com relação aos artesãos considerados inferiores no livro IX (República, 590c2-5), os banausoi e os kheirotekhnai, frequentemente associados aos que realizam trabalhos manuais. Por neles a parte melhor ser incapaz de comandar as criaturas cobiçosas que neles residem, não podendo senão servi-las e afagá-las, é preciso que ele seja escravo de um melhor que não está nele mesmo, de um

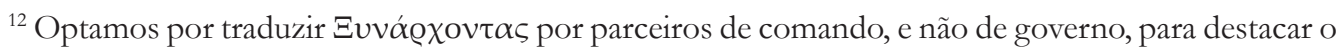
contraste entre os governantes nas outras cidades e os governantes na cidade dos personagens, já que o que está em jogo nesse argumento de Sócrates é a unidade da cidade e a philia entre seus cidadãos, o que não ocorreria, segundo ele, nas demais cidades conhecidas.
} 
comandante de fora (República, IX, 590c7-d8), assim como as crianças ainda não plenamente educadas. Essa é a passagem considerada inspiradora da tese aristotélica da escravidão natural - citada por Newman, um comentador da Política de Aristóteles do final do século XIX, por sua vez citado por Vlastos para corroborar sua tese, embora o próprio Newman só veja essa única passagem como sugestiva de uma doutrina da escravidão natural, "que parece, entretanto, ter sido perdida de vista nas Leis, onde pouca, se alguma, atenção aparece sendo dada aos interesses éticos do escravo" (Newman, 2010, p. 144).

Tal escravidão é, porém, amenizada por Platão, que põe Sócrates afirmando em seguida que esse artesão não é comandado para seu prejuízo, como pressupunha Trasímaco, mas porque é melhor para todos ser governado pelo divino e sábio, “a fim de que todos sejamos semelhantes e amigos o máximo possível". ${ }^{13}$ De fato, é nítida a semelhança entre os termos utilizados por Platão nessa única passagem e os utilizados por Aristóteles na Política. Em sua defesa da escravidão natural ( $\phi u ́ \sigma \varepsilon \iota)$, diferente da escravidão conforme

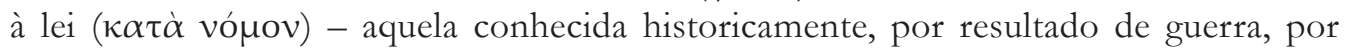
exemplo ${ }^{14}$-, Aristóteles pensa o senhor e o escravo naturais como complementares um ao outro: o escravo servindo com o corpo que o senhor não tem, ${ }^{15}$ e o senhor oferecendo o

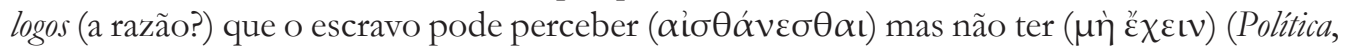
I, 1254b24).

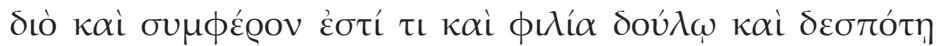

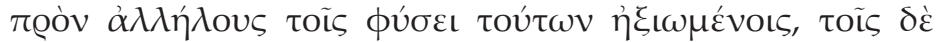

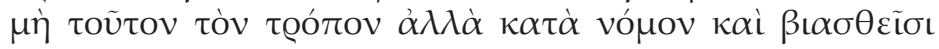
toủvatíov.

Por isso há uma vantagem e amizade recíproca entre o escravo e o senhor estimados como naturais, enquanto entre os que não são estimados desse modo, mas conforme a lei e tendo sofrido violência, se dá o contrário (Política, I, 1255b13-16).

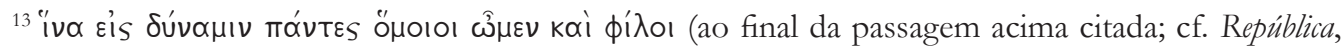
590d7-8).

${ }^{14}$ Cuffel 1966, p. 331, elenca 4 meios para se adquirir escravos: "havia aqueles nascidos na casa, aqueles capturados em guerra, aqueles que eram comprados e aqueles que teriam sido escravizados por dívida”. A autora salienta que, apesar de se atribuir a Sólon uma lei que teria abolido este último tipo de escravidão, uma passagem em Isócrates (Discursos, xiv, 48) lançaria dúvidas sobre essa proteção legal aos pobres.

${ }^{15}$ Política, I, 1255b10-12: "O escravo é uma parte do senhor, conquanto que uma parte animada separada

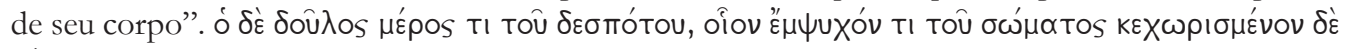
ú́pos. Política, I, 1254b28-31: "Portanto, a natureza quer fazer os corpos dos livres e dos escravos diferindo-se; uns fortes para o serviço necessário, os outros eretos e inutilizáveis para tais atividades,

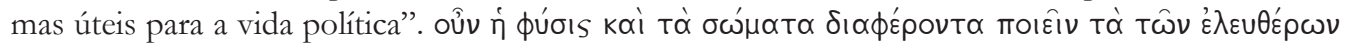

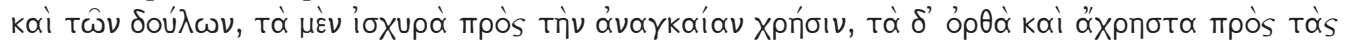

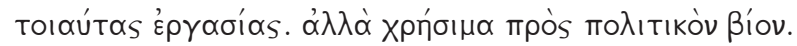


Aristóteles ainda se refere à escravidão natural como "o melhor" ( $\beta \varepsilon ́ \lambda \tau \iota$ ov, em

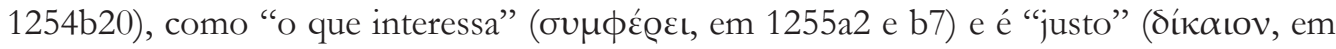
1255a2).

A questão é que, embora possamos concordar que há uma influência dessa passagem da República na teoria aristotélica da escravidão natural, a maneira como Platão se refere ao escravo em todas as demais ocorrências do termo doulos e oiketēs no diálogo é pejorativa, envolvendo frequentemente violência ( $\beta$ í $\alpha$ ) e jugo. Também Morrow (1939), num artigo em que compara a visão platônica da escravidão (detendo-se, principalmente, na legislação elaborada nas Leis) com a escravidão na Grécia e, especificamente, com a legislação ateniense, mostra como o termo douleia geralmente é usado pelo filósofo no sentido de ausência de direitos políticos ou de independência política, denotando inferioridade, servilismo, subordinação, apontando numerosas passagens na obra de Platão para apoiar sua tese (Morrow, 1939, p. 187). Por tudo isso não nos parece possível associar a relação entre governantes e governados com a escravidão, a não ser com uma lente aristotélica, entendendo as vantagens recíprocas, os interesses mútuos como a base da complementaridade entre os diferentes grupos existentes na cidade.

Portanto, voltando ao texto como escrito por Platão, das duas, uma: ou ele é irônico o tempo todo ao declarar a amizade, a concórdia e a harmonia entre os cidadãos, enquanto haveria de fato uma relação de submissão entre governados e governantes; ou acreditamos no texto e nas palavras usadas pelo filósofo para descrever essa mesma relação. Dando adesão à segunda opção, temos que confiar que, embora haja grupos na cidade incapazes de serem sōphrones por si mesmos, eles, por algum processo persuasivo, sabedores de que devem obedecer às leis, preservar os costumes, são sōphrones por algo que lhes é externo. Devemos lembrar, todavia, que esses não abrangem a totalidade dos governados, e sequer a totalidade dos artesãos.

Vlastos prefere apostar numa terceira alternativa, provavelmente inspirado pela visão aristotélica da escravidão: Platão não é irônico, mas usa a palavra douleia de maneira muito própria, sem associá-la à dureza e à desonra, num sentido virtuoso e amigável (Vlastos, 1941, p. 292). Não nos parece ser esse o caso quando o filósofo tantas vezes associa a escravidão à tirania, tanto na alma quanto na cidade. São muitas as passagens que atestam o sentido negativo de sujeição e servilismo, de modo que não nos parece correto, repetimo-lo, usar a ideia como metáfora para falar da relação entre governados e governantes na cidade excelente. Se assim fosse, não haveria razão para a sōphrosynè estar presente em todos os grupos de cidadãos. Entendendo-a como obediência ao superior (um de seus sentidos populares ${ }^{16}$ ), ela poderia se encontrar apenas entre os artesãos e guardiões auxiliares.

Morrow (1939), numa tentativa de encarar o problema da escravidão em Platão sem escamotear o que ela teria de cruel aos olhos modernos, aponta, numa análise detalhada e circunstanciada, como a legislação platônica (presente nas Leis) seria, em geral, muito mais

\footnotetext{
${ }^{16}$ Defendemos em Haddad 2010 que o sentido que Platão dá à sōphrosynē na República se distancia gradativamente da maneira como o termo era usado popularmente naquela época e cultura.
} 
rigorosa e menos liberal com os escravos do que a legislação ateniense de sua época. Em momento algum Platão se coloca contra a instituição da escravidão (na própria República já o havíamos visto), assim como ele não reserva aos escravos nenhuma lei que evite os abusos, as arbitrariedades e a brutalidade de seus senhores (Morrow, 1939, p. 201).

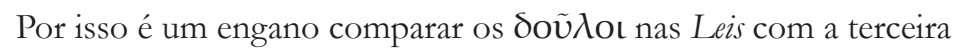
classe na República, pois os últimos, embora subordinem sua função no Estado, ainda possuem direitos legais e capacidade legal. Alguém teria de considerá-los como destituídos não apenas de poder político, mas também de cidadania e de direitos civis, antes de sua condição ser análoga à dos escravos nas Leis. Aquele que tem essas distinções em mente dificilmente concordará com Ritter que a maioria dos homens preferiria ser escravo a ser cidadão no Estado de Platão, ou que a atitude de Platão está essencialmente de acordo com o reconhecimento cristão do valor de todos os homens (Morrow, 1939, p. 201, n. 1).

Além dos bons argumentos de Morrow, o livro IX, em boa parte dedicado à exposição acerca da tirania, contribui para nossa contestação. Escravos são os governados num governo tirânico. E escrava é a alma em que o melhor não foi desenvolvido e que serve ao pior. Leia-se, por exemplo, o diálogo travado em 577c-d, que faz um contraponto bem acentuado àquele diálogo que citamos e que tratava dos nomes dados aos governantes e governados na cidade excelente:

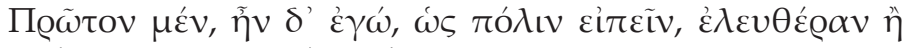

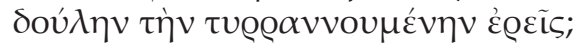

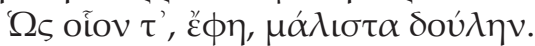

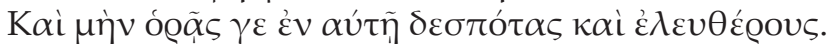

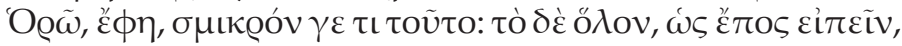

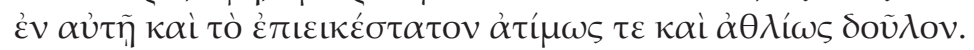

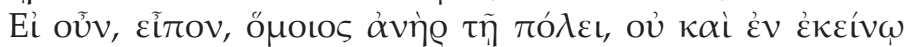

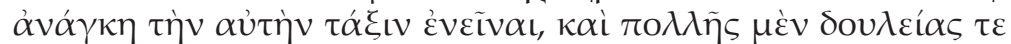

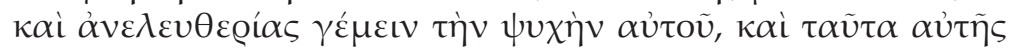

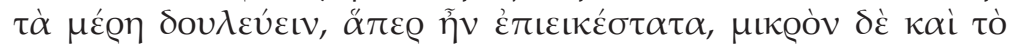

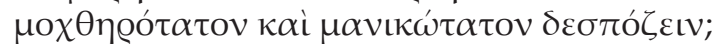

Avó $\gamma \kappa \eta, \varepsilon ้ \phi \eta$.

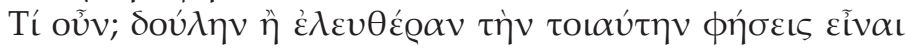

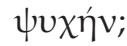

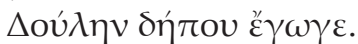

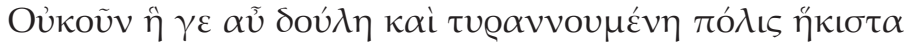

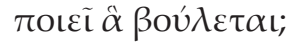

По $\lambda \dot{v} \gamma \varepsilon$.

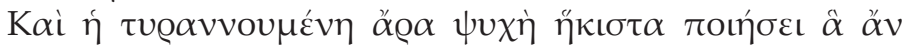

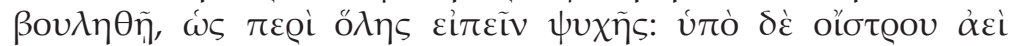

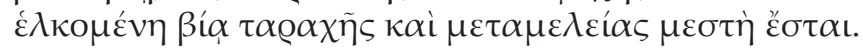




\begin{abstract}
Para primeiro falar da cidade, disse eu, dirás que a cidade tiranizada é livre ou escrava?

Ela é escrava o máximo que pode, disse.

E mesmo assim vês nela senhores e homens livres.

Vejo, disse, mas em número bem pequeno; o todo nela, por assim dizer, parte a mais comedida, é desonrosa e miseravelmente escrava.

Se, portanto, disse, o homem é semelhante à cidade, também não vai acontecer de nele necessariamente existir a mesma ordenação, e de sua alma estar cheia de muita escravidão e servidão, e de justamente as partes mais comedidas se tornarem escravas, enquanto a inferior, mais perversa e louca exerce a soberania?

Necessariamente, disse.

E então? Escrava ou livre dirás ser essa alma?

Escrava, sem dúvida.

Não é o caso, portanto, que a cidade, por sua vez, escrava e tiranizada faz tudo que quer?

Claro que não.

Também, por conseguinte, a alma tiranizada não fará tudo que quiser, para falar da alma inteira; sempre arrastada pela violência da fúria, será repleta de turbulência e remorso. (República, 557c-d).
\end{abstract}

Embora nos seja claro que não se podem confundir os governados com escravos, nem do ponto de vista político, legal, nem de uma perspectiva metafórica, permanece não respondida a questão sobre como se daria a escravidão na cidade da República. Mantendo a possibilidade da escravidão de bárbaros como espólio de guerra, Platão se revela um ateniense coerente com seu tempo. Não só no sentido de achar legítimo que o derrotado numa batalha se tornasse escravo, mas também no sentido de, como qualquer grego desse período, conviver com a possibilidade real de ele mesmo se tornar um. Para além dos muros da cidade, a "garantia de segurança individual" inexistia, além de as guerras serem frequentes e oferecerem não mais que três alternativas ao combatente: "vitória, morte ou escravidão" (Cuffel, 1966, p. 326).

Alguns autores, conforme narra Diógenes Laércio, afirmam que de fato Platão chegou a ser vendido como escravo em Egina, após ter desagradado o tirano de Siracusa, Dionísio. Em Egina, teria sido primeiramente condenado à morte, por lá ter sido estabelecida a pena capital para todo ateniense que chegasse ao território, mas, após alguém alegar, zombando, de que se tratava de um filósofo, a assembleia teria decidido vendê-lo como se fosse um prisioneiro de guerra. Aníceris de Cirene, presente casualmente, o teria resgatado por vinte ou trinta minas (Diógenes Laércio, III, 18-20).

Desse prisma, como não ver a escravidão como algo da ordem do acaso, da fortuna? Antes de qualquer justificação, legitimação ou qualquer consideração acerca da escravidão, está o fato inegável de que pouco ou nada pode um homem fazer para impedir que seja escravizado. Por outro lado, as guerras (a forma mais comum de se obter escravos direta ou indiretamente) não são assuntos de um homem comum, mas da polis. Cabe ao Estado pensá- 
las e realizá-las dentro de determinados fins. E talvez fosse isso que Platão tivesse em vista

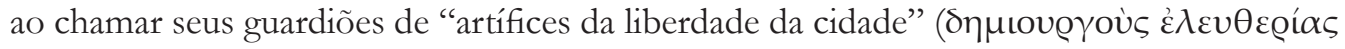

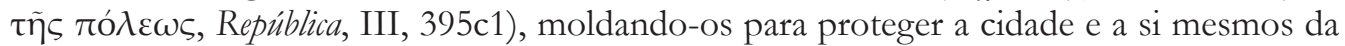
escravidão, proibindo-lhes, por exemplo, de fazer a imitação de escravos (República, III, 395e6-7) e abolindo de sua formação pela mousikè os versos de Homero que revelam um Aquiles que preferiria estar vivo e servir $(\theta \eta \tau \varepsilon v \varepsilon ́ \mu \varepsilon v)$ a comandar os mortos (República, III, 386c). É preciso, diz Sócrates, que os guardiões temam mais a escravidão do que a morte

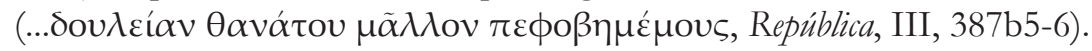

\section{REFERÊNCIAS}

\section{Textos antigos}

ARISTOTLE, Politics. With an English translation by H. Rackham. Cambridge MA: Harvard University Press, 2005. Reimpressão da segunda edição de 1944. Primeira edição de 1932.

DIÔGENES LAÊRTIOS, Vidas e Doutrinas dos Filósofos Ilustres. 2. ed. Tradução do grego, introdução e notas de Mário da Gama Kury. Brasília: UnB, 1977.

PLATON. La République, livre I-III. Texte établi et traduit par Émile Chambry. In: Oeuvres Complètes. Paris: Les Belles Lettres, 1970. t. 6.

PLATON. La République, livres IV-VII. Texte établi et traduit par Émile Chambry. In: Oeuvres Complètes. Paris: Les Belles Lettres, 1946. t. 7, $1^{\text {re }}$ partie.

PLATON. La République, livres VIII-X. Texte établi et traduit par Émile Chambry. In: Oeuvres Complètes. Paris: Les Belles Lettres, 1934. t. 7, $2^{\mathrm{e}}$ partie.

PLATON. Les Lois: Livres III-IV. Texte établi et traduit par Édouard Des Places. Paris: Les Belles Lettres, 1994.

PLATON. Les Lois: Livres XI-XII. Texte établi et traduit par A. Diès. In: . Oeuvres Complètes. Paris: Les Belles Lettres, 1976. t. 12, $2^{\mathrm{e}}$ partie. pp. 5-89.

\section{Textos modernos}

CUFFEL, V., "The Classical Greek Concept of Slavery", Journal of the History of Ideas 27:3, Jul.-Sep. 1966, pp. 323-342.

HADDAD, A. B., “Sophrosýne em República IV,431b5-d2”, Dissertatio 32, verão 2010, pp. 193-217. MORROW, G. R., "Plato and Greek Slavery”, Mind, New Series, 48:190, Apr. 1939, pp. 186-201.

NEWMAN, W. L., The Politics of Aristotle. With and introduction, two prefatory essays and notes critical and explanatory. Cambridge: Cambridge University Press, 2010. v. 1. Primeira edição de 1887.

VLASTOS, G. Slavery in Plato’s Thought. Philosophical Review, 50:3, May 1941, pp. 289-304. 